\title{
Working with the Waverley integrative framework (WIF). Exploring the experience of counsellors, trained in the Waverley integrative framework (WIF), in incorporating the framework into their therapeutic practice.
}

\section{Charlotte Wears}

\begin{abstract}
Aim/research question: This paper examines the experiences of five participants from within Waverley Abbey College alumni with between ten- and sixteen-years' experience in clinical practice using the Waverley integrative framework (WIF): a counselling framework built on a biblical philosophy, and taught since the 1980's.

Method of data collection and analysis: An interpretative phenomenological approach was employed to engage with the lived experience of participants.

Findings: Three superordinate themes emerged from the analysis. Therapist experiences of assimilating theory, of developing practice, and discovering a sense of becoming - each with three subordinate themes.

Implications for counselling: In working with the WIF, a process of ontogenesis was identified, where participants described moving from perplexity towards embodiment. A symbiotic relationship between theory, practice and research was found to sustain and develop WIF practitioners and the framework itself. Reflective practice, further research and continuing professional development are offered as recommendations to enrich the development journey of the WIF, its therapists, its paradigm community and its standing within the field.
\end{abstract}

\section{Introduction: Integration and the Waverley integrative framework}

The current research

The Waverley integrative framework (WIF) approach to counselling has accompanied many cohorts of students on their training pathway, taught at Waverley Abbey College (WAC) and beyond. Yet little is known, except anecdotally, about the way the WIF carries into the philosophical and skills formation of its students.

Review and scrutiny into the practical outworking of the framework can only enhance the quality of teaching, the delivery of effective and ethical clinical, and improve practitioner credibility and public standing (Bond 2004:4). In asking 'What is the experience of counsellors, trained in the Waverley integrative framework, in incorporating the framework into their therapeutic practice?', this study presents the experiences of qualified counsellors who have translated and incorporated the WIF into their practice. 


\section{Genesis of the Waverley integrative framework}

The WIF is an integrative relational framework for counselling, underpinned by a Christian anthropology with a holistic view of human functioning (Kallmier, 2011:205, Hughes, 2002:13,1526). Since its conception by Selwyn Hughes in the 1980's, the WIF has been academically explored and expounded upon by a small group of contributors (Hughes, 2002; Kallmier, 2011; Ashley, 2015; Armitage (unpublished thesis), 2018).

Hughes' conceptualisation is deeply grounded in the work of Crabb, whose personal, rational, volitional and emotional 'capacities of personhood' (Crabb, 1987:93-6) form the basis of the WIF's 'five areas of [human] functioning' (Hughes, 2002:64,194; Kallmier, 2011:47-50), to which Hughes adds a physical area (see figure 1). Hughes adopts Crabb's two 'crucial [human] longings' for security and significance (Crabb, 1977:59,191) and adds another: self worth.

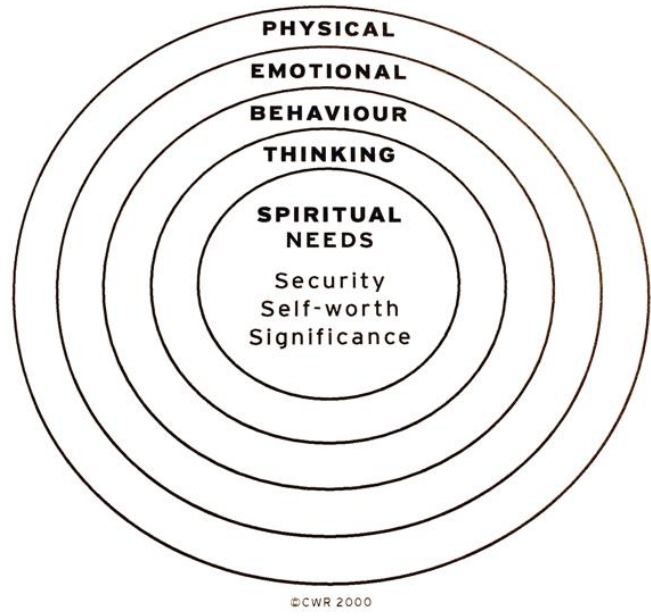

Figure 1: Hughes' conception of the Waverley integrative framework (2002).

\section{Integration with psychology}

The WIF integrates considerably from cognitive behavioural therapies (Steele, 2014:208; Hurding, 2003:301). Ashley recognises insights gleaned from Ellis, Adler and Rogers, $(2015: 62,125)$ and influences from Erikson's (1980) developmental model; Frankl's emphasis on meaning (1946); and Bowlby's attachment theory (1969) (Ashley, 2015:67,72,114-115). The concept of 'deep' or 'core' longings (Crabb, 1987:15; Hughes, 2002:107-112) shows alignment with the 'universal psychological principles' Seager et al have substantiated (2012, noted by Ashley, 2017:18), and resonate with both Maslow's hierarchy of needs theory (Maslow, 1999) and 'core conditions' Rogers deems 'necessary and sufficient' (Rogers, 1957:95-96) from the person-centred therapist.

\section{Development}

Kallmier's contribution is outlined in his primer Caring and Counselling: An Introduction to the Waverley Model of Counselling (2011). He overtly advocates application of the WIF in secular contexts, opening the framework considerably to engagement with all clients respecting, and regardless of 'their own faith belief (or none)', their 'gender, age, ethnicity, culture, class, sexuality, religion and belief' (p205). There is also an emphasis on relationships with others and greater fluidity between the areas of functioning (see figure 2 ). 


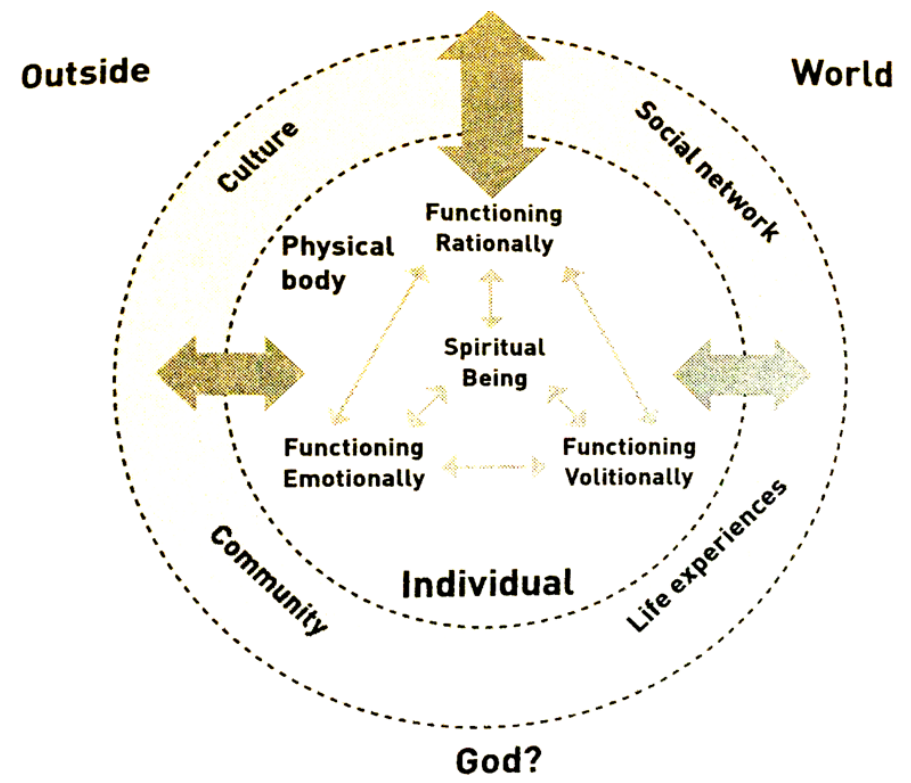

Figure 2: Kallmier's conception of the Waverley integrative framework (2011).

'The Bible, Wisdom and Human Nature' is Ashley's (2015) critical assessment and development of the WIF. His work argues for 'evolution, not 'revolution' of the framework (2015:128). Ashley recognises in Hughes' model marks of its modernist beginnings; elements that have structuralist and reductionist leanings, he critiques the closed 'self in isolation' diagram (2015: 7,41,83-87). His 'evolution' does not reject Hughes and Crabb's conception of self, so much as highlight how the influence of their modernist context insinuates an individualism somewhat incongruent with the prominence relationality is given in their theoretical grounding ( $p 77$ ) (see figure 3 ).

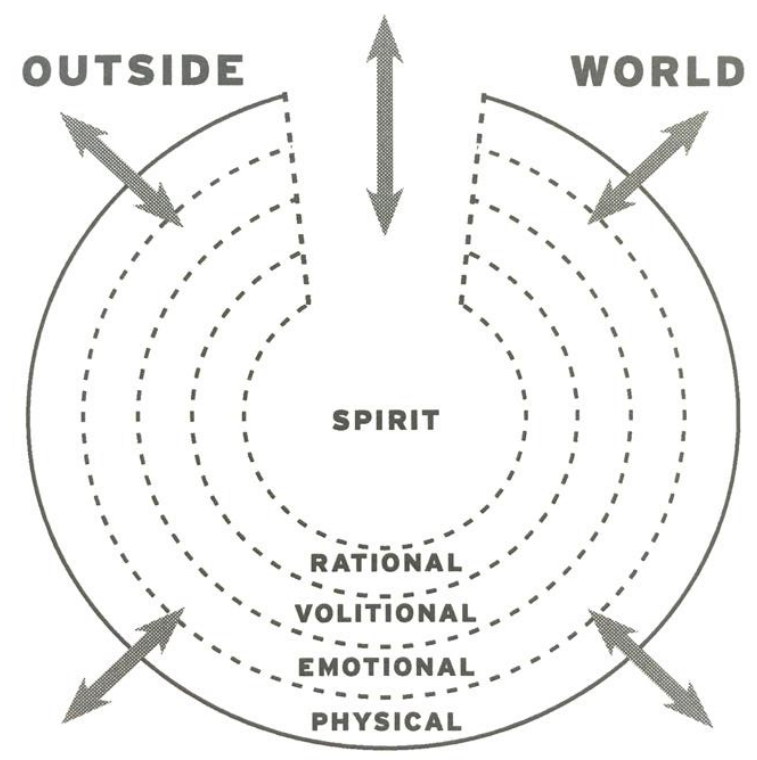

Figure 3: Ashley's conception of the Waverley integrative framework (2015). 
Ashley cites empirical research findings (2015:129) as support for a heightened emphasis on the role of relationality, both in human nature and in therapeutic attempts to facilitate change ( $p 128)$. Indeed, Ashley remarks that Christian approaches to counselling have a legacy rooted in depth of relationship, harmonising with the likes of Petruska Clarkson (2003) and Carl Rogers (1951) in deeming the therapeutic relationship of 'central importance[...] a key agent of positive change' (Ashley, 2015:129). Object relations theory, attachment theory and neuroscientific findings are drawn into the integration of Ashley's grounding for the critical importance of human relationality (Ashley, 2015:112-117).

The situation of the WIF within the burgeoning field of psychological integration will now be explored.

\section{The emergence of integrative counselling}

Integrative frameworks have developed in response to an aspiration, voiced by Hollanders, for 'a philosophy out of which a meta-paradigm can emerge... a central focus of endeavour... alongside the research-focused quest for ever more effective practice' (1999:488). The WIF is well-positioned to be relevant: a framework that enables constructive integration of concepts, skills, theories and interventions from varied provenance, rooted in a fundamental philosophy.

\section{Developing as an integrative practitioner}

Giovazolias (2005), has published autobiographical experience of developing as an integrative practioner, as has Nuttall, (2008). Giovazolias' experience, drawn from individual experience and self-reflexivity, differs from the choral perspective of particpiants and researcher this IPA study seeks to elicit, but it does allow an intertextuality in having potential resonance with the experience of WIF-trained counsellors undertaking a journey of integrative development. To date, only one IPA study has been carried out focused on the WIF (Armitage, unpublished, 2018), leaving considerable scope for investigation

\section{Literature on the Waverley integrative framework}

Accounts of the WIF in practice are limited to Hughes' original illustrative vignettes (2002) and Armitage's (unpublished, 2018) investigation into student experience of the framework. The former are connected to the theoretical formation of the WIF; the latter, perceptions from the personal formation of trainee practitioners. Armitage's findings substantiate the impact of the WIF upon persons newly-immersed in it (notably self-awareness, emotional processing, spiritual development, openness to change, and growth in compassion for the self and others. p3, 53, 56, $57,59,60)$, but the learning environment 'which was congruent with the WIF's core values' (p61) does not correspond with clinical scenarios where the WIF is exercised professionally.

Current curricula at WAC support their advocation that students 'engage in critical analysis of the Waverley model' and formulate their learning into an individual approach (Ashley, 2015:127-128; Kallmier, 2011:205). Yet despite ten years of university-level WIF-trained therapists existing in the psychotherapeutic pool, no research or data demonstrates lived ways in which this is done, or what it feels or looks like. 
This research has potential to contribute to WAC's commitment to maintain the WIF's responsiveness to the latest research and its application to the contemporary context' (Ashley, 2017:19).

\section{Methodology}

This study explores the lived experience of qualified counsellors who have translated and incorporated the WIF into their practice using interpretative phenomenological analysis (IPA) developed by Smith (1997).

The study recruited five participants, within the range suggested by Smith, Flowers \& Larkin, allowing for 'the development of similarities and differences across cases' (2009:51). All participants were alumni from WAC in the UK. All participants had trained and qualified in the WIF: two had a diploma, one had a BA and two had MAs. They had all been in active practice using the framework for ten to sixteen years, (ten years as a modal average), although no criteria was set to select according to length of practice.

\section{Findings}

In analysing the interview data, three emergent superordinate themes and nine subordinate themes were selected as germane to the research question: What is the experience of counselors, trained in the WIF, in incorporating it into their therapeutic practice?

These themes are explored here, with excerpts from the original interviews and reference to extant literature. In line with decisions around ethical practice, all participants are referred to by gender-neutral pseudonyms, (Alexis, Blake, Cameron, Dana and Eliot). 


\section{Table of Grouped Themes:}

\begin{tabular}{|c|l|}
\hline Superordinate themes & Subordinate themes \\
\hline 1. Assimilating theory & Beginnings: a sense of tangle \\
A Christian philosophy to 'hang on to' \\
Grasping the Framework
\end{tabular}

Table 1: Summary of superordinate and subordinate themes.

\section{Superordinate theme 1: Assimilating theory}

Participants' experiences suggested incorporation of the WIF into therapeutic practice begins at the earliest stages of learning, initiating a process of ontogenesis: development from the earliest stage towards maturity.

\section{Subordinate theme A - Beginnings: a sense of tangle}

The majority of participant accounts described introduction to and theoretical assimilation of the WIF as challenging. Cameron's perception testified to a universal struggle and sense of bombardment: 'Everybody finds it hard to grasp to start with; there's quite a lot coming at you.' Selfdoubt and uncertainty were evident in Dana's self-questioning delivery of the following statement:

'I don't think at that time I really, really deeply understood it [the WIF]... it was all kind of new information and we were learning it... I'm not sure it kind of sank deeply, if that makes sense.'

While exposure to a new discipline, new ideas, and taking on the role of student accounts for some of this (Rønnestad, et al., 2019), Norcross compares students of integrative psychotherapy to children within a bilingual family: 'delayed initially in the acquisition of skills' and 'more apt to feel frustrated.' (Norcross, cited In Hollanders, 1999:492). Blake, a self-identified 'fast learner', experienced this frustration in a singular way: 
Working with the Waverley integrative framework: Exploring the experience of counsellors, trained in the Waverley integrative framework (WIF), in incorporating the framework into their therapeutic practice.

'I was frustrated by it; I wanted to be able to offer more than that... [there was] so much more to learn than just this model, this framework.'

Subordinate theme B - A Christian philosophy to 'hang on to'

All five participants in this study identified as having a personal Christian faith. The foundation of the WIF in a Christian worldview was essentially resonant with the sample's faith grounding. Alexis stated: 'As a Christian, I know I've got my Christian viewpoint anyway, so I kind of sat with that and just kind of worked with it [the WIF] that way.' Personal faith finding anchor within the familiar spirituality of the framework allowed new learning to be knitted into an established understanding of the world.

Among these accounts, a collective sense of soul-deep security and familiarity emerged, together with the possibility of a like-minded community under common constructs (Gergen, 2009), arguably positioning the WIF as the kind of 'meta-paradigm' that can be 'adopted by individuals and communities under the same mix of influences' (Hollanders, 1999:487). Alexis demonstrates this collective (we) and personal (me) belief held in tension:

'We've been designed with these needs and that kind of helps me just to sort of see a basis. We're looking at how... the whole kind of philosophy sits with my Christian viewpoint. It backs everything up for me from where l'm sitting.'

Dana articulated a process of using the WIF to critique therapeutic models: 'OK, so how does this fit with a Christian worldview?' That fits, that doesn't fit.' There is a sense of curating and collecting theories, ideas and interventions. Like a seed in fertile ground, germinating and beginning to lay down roots, even in complete darkness, so these participant accounts suggest the WIF has offered philosophical grounding, and cultivated critical thinking in a place of bewilderment.

\section{Subordinate theme C - Grasping the framework}

Participant accounts indicated an emergence out of confusion. Alexis' assessment was that eventually the WIF 'just makes sense' - a phrase that also ran like a refrain through Dana's interview.

The WIF is a framework, like a jewellery setting or a wall mount, designed to hold something. Images that convey how this is experienced were frequent in all interviews. The following metaphor demonstrates how, having grasped the WIF, Alexis conceptualised its role in ongoing practice:

"I picture it as this big framework that I hook everything else onto. This basic frame... I can sort of hang everything on it... and whatever doesn't align with itself... I don't have to take.'

\section{Superordinate theme 2 - Developing practice}

Participants identified clinical practice as a cultivating force within the development of a WIF-based approach. These findings demonstrate something of the role experience plays in the process of ontogenesis through the participants' own meaning-making of their counselling practice and understanding of how it has shaped and challenged their learning. 


\section{Subordinate theme A - Authentic practitioners}

Participants described experiences of deep authenticity in the therapy room. Alexis described a professional persona that 'doesn't have to go outside of who I am as a person', openly stating: 'I'm a Christian; that's part of who I am and that's in every area.' In acknowledging a deep affinity between the WIF and firmly held personal values, Alexis also articulated a sense of freedom and empowerment within a world that held the possibility of disenfranchisement: "I can be myself as a counsellor, which I think a lot of people can't if they've not been able to incorporate a framework that can bring in faith.'

The benefits of bringing a congruent self as a therapist are documented (Steele, 2014:149-151; Rogers,1957:223-4). Alexis' observations suggested a WIF approach had been empowering and enabling in a context where therapists of faith might feel apologetic, silenced or secretive. In allowing an integrated and whole self to be brought to the client, therapist personhood had not been required to fracture, enabling scope to realise Cozolino's suggestion that 'The private personal world of the therapist is in fact, one of our most important tools' (2004:xviii).

Participants' experience of authenticity extended beyond the intramural: professions of openhearted, beneficent, respectful, valuing and hopeful attitudes towards clients emerged that held scriptural resonance (Galatians 5:13-14, 22-26) aligned with the wisdom of psychological theory (such as Clarkson, 2003; Frankl, 1946/2004; Rogers, 1951,1957; Thompson, 2010) and that of psychotherapeutic governing bodies, (e.g., BACP, 2018: Principles, personal moral qualities). For example, Alexis described a faith-inspired universal optimism, equity and inclusive openness towards clients:

'We're all made in God's image. That is humanity. So, whether you believe it or not... it helps me to be a lot more open and... hopeful, really, in just being able to come alongside people.'

\section{Subordinate theme $B$ - Fluidity above formulation}

Jung's well-used quote resonates well with these participants taking theory into practice: 'put them aside when you touch the miracle of the living soul. Not theories but your creative individuality alone must decide' (Jung, 1953:73).

Cameron repeatedly asserted the Framework was 'extremely practical', but admitted 'I'm not really, on the whole, a "by the book" person. I do tend to go with the flow of the client.' Instead, he advised a more fluid approach: 'Keep the basic skeleton; work from that, and allow yourself to tailor-make what you're doing to the actual needs of your counselee.' In this Cameron was not alone.

Kallmier's presentation of the WIF as a defined structure and step-by step process (2011) may influence critique by participants that the Framework is 'reductionist' and 'prescriptive'. It is emphasised during training, however, that it is 'not a straitjacket' (Ashley, citing Hughes, 2015). Alexis illustrated a felt absurdity in how an attempt to literally translate Kallmier's process into practice would appear: 'Ooh, I'm working the emotional area, and, ooh, we're working in the rational area, and, ooh!, ooh!, we're going into the spiritual area.'

Returning to a serious tone and demeanour, Alexis qualified, 'You have to remember that, in theory, that happens; but when you're actually counselling, you're all over the place, you know.' This parody 
raises the matter of teaching. An over-simplified, prescriptive structure may be necessary to break down the WIF for instruction and assimilation (especially in a context already described as theoretically overwhelming and confusing to a novice). But a shift appears to take place.

Blake described application of the framework as more fluid than formulaic: 'I don't necessarily follow the phases very well, I just let it all... happen naturally', while concerned that 'some counsellors maybe try too hard to follow it strictly because it is very emphasized in our training.' Blake believed 'that's a good thing so that it's clear and they preserve the framework.' An express tension surfaced between the need to learn clearly, with a level of theoretical purity for preservation and maintenance of the framework, alongside the need to practise this learning in a far more flexible manner. Blake illustrated the problem of keeping to Kallmier's tri-phasal structure (2011:133-138) within an area of professional expertise: 'You'd be missing the struggles of an ADHD person if you tried to interpret the stages of the presenting problem and all that resolution.'

\section{Subordinate theme $\mathrm{C}$ - Framing practice}

Experience of the WIF within practice was a very rich vein, providing plentiful findings around how the WIF is practised and how it is received. As participants spoke of ways in which the framework accompanied their personal evolution as therapists, a growing sense of partnership arppeared between the framework itself and those practising it. Hughes' diagram of the areas of functioning (2000, see diagram 1) emerged as a particularly central element within practice. Three of the five participants regularly drew the diagram for the client within a session. In many ways the diagram appeared in an affiliate role; a close consort in: 'risk assessment', in 'conceptualisation', 'working your way through the whole skeleton' (pacing the work), 'intervention choices for attending to the areas' and in 'psycho-education'.

The WIF's three core longings: security, self-worth and significance (Hughes, 2002:109-112) received frequent reference from participants. Alexis identified these terms as also being popular in current vernacular and within secular ideologies:

'I think they translate very, very easily to be able to talk about it [the spiritual core] and understand it and see where maybe there are some unhealthy ways in which they're getting these met.'

Hughes' 'three S's' (as all participants familiarly abbreviated the core longings to) were viewed among the sample as highly relatable to clients. Described by Alexis as 'foundational longings and needs', and given substance and magnitude, in the main, through biblical grounding (as expounded by Hughes, 2002:100 and Ashley, 2015:64-7), participants also noted that correlations can be observed with Erikson (1980) and Maslow's (1999) psychosocial models, and Winnicott (1965) and Bowlby's (1969, 1988) work on attachment and relational and intersubjective depth psychotherapy.

Alexis explains the concept of core longings to clients using an organic metaphor:

'These are almost like the three roots that everything else can come out of... we all want to be loved. We all want to feel that we belong. We all need to have value. We all need to have a purpose and meaning.'

The concept of roots delving deep into the earth, questing for moisture, becomes a parallel to the longing, reaching spiritual self for its most coveted needs. This metaphor holds notable 
synchronicity with Eliot's depiction of the areas of functioning, illustrating how these 'roots' connect to systemic health:

I'll often say... picture a tree cut down, and all the circles in a tree. They're all part of the same tree, it's still an oak tree... but they are all important circles in that tree's life and these [areas of functioning] are in yours.'

Assimilating theory has been compared to a seed taking root in the soil of the WIF. Perhaps development in practice can be likened to a burgeoning plant: the 'becoming' of a therapist.

\section{Superordinate theme 3 - A sense of becoming}

With between ten and sixteen years' experience as qualified therapists, all participants sat within Rønnestad et al's criteria for either 'established therapists' (7-15 years) or 'seasoned therapists' (15-25 years) (2019:223). Accounts of how their incorporation of the WIF has matured during their careers will be considered here, alongside their hopes for future evolution.

\section{Subordinate theme A - Leaving and returning}

Two participants described having left the WIF behind. Dana recalled, 'I... left it on the shelf... and looked more to the different modalities and just sort of found my own path.' But on returning to the WIF as an experienced therapist, Dana felt 'It just made a lot of sense... so I kind of just fell back in love with it, really.' Alexis, too, felt that 'I've kind of come back to the WIF; I think I went away from it.' The interposing journey appeared to have been meaningful: 'I think maybe that's because as I've grown as a counsellor myself and I've got my own style.'

Learning, leaving and returning has resonance with that of a child's developmental journey in relationship with a parent. Return as an adult may involve warmth and familiarity but also a distinctive individuation established through the synergy of imparted learning and lived experience (Arnett, 2016).

The passing of time, the decision to return, and the acknowledgement and appreciation of the WIF in a new way all appear significant. While some may never engage with the WIF and some may leave it and not return, Alexis' string of realisations suggested a greater complexity for the committed WIF practitioner than simply a departure and a return:

'I think I went away from it. Not entirely, but just kind of maybe in using it unconsciously, and maybe I've started to see how consciously I do fit it in because I think I might have taken it on board and just did it. Did it, and not realise how I was working with it. But I think that was quite hard for me to think "How do I incorporate this?"'

The discovery of the WIF as present, essential and dynamic within Alexis' practice suggested a transition from it being something one does, to integral in what one is becoming.

\section{Subordinate theme $B$ - Becoming and embodying}

Eliot articulated how the WIF 'permeates, but in a kind of unconscious way', suggesting something systemic had occurred. Alexis expanded on this 'permeation': 
'It's difficult, isn't it? because it's sort of integrated into everything I do, so it's quite difficult to say, oh, this is where I use the WIF when I look at it now ten years, eleven years down the line. I can see that it's integral... it's in everything. I'm using it more without consciously realising that I'm using it... I think it's become part of me.'

It appeared the WIF could not now be disentangled from other aspects of practice. 'In everything', it had become a mode of being: a reflexive way of functioning, both 'integrated' and 'integral'.

When asked whether a WIF-approach is exercised within Eliot's own personhood, the reply was 'probably subconsciously, I do apply it', followed by an 'in-the-moment' self-analysis of Eliot's personal awareness of and attending to the areas of functioning, in clear resonance with Armitage's findings among students of the WIF, of personal growth, self-understanding and awareness, leading to a self-compassion (unpublished thesis, 2018:36). Mearns' (1997) model of personal development also suggests growth takes this pathway: self-awareness, selfunderstanding and self-experimentation.

Ontogenesis is a process of development: an organism moving from the earliest stage towards maturity. If participants' experiences of exposure to theory were compared to the germination of a seed, and development in practice to rooting, stemming and producing leaves, this phase might suggest flowering and pollination.

Across the sample, an unconsciousness about the incorporation of the WIF into the therapeutic self was evident. During interviews, it appeared to emerge, bud-like, into the consciousness of the therapist-as-organism. It was here that participants appeared most settled, comfortable and creative, describing a state of intuitive embodiment of the WIF within their practice. Cameron recognised: 'I do it [recognise areas of functioning] automatically, you see; I don't think about it anymore.'

Each participant spontaneously turned to images or ideas to give a sense of how incorporation of the WIF had come to feel for them. A common theme (perhaps unsurprisingly for a framework) was that of structure. Blake's remarks gave a vivid sense of something inconspicuous, though fundamentally essential and containing:

'How I'm conscious of it? It's just a framework. It's like when I'm taking a bath, I'm more conscious of the water, but if the tub wasn't there, I might not have the water.'

It appears the WIF has been enabling for participants; envisioned and absorbed as a structure that is resourcing and secure, lending strength and sanctuary to practitioners.

\section{Subordinate theme $C$ - Augmentation and progression}

Three of the five participants voiced a desire for WIF-specific continuing professional development (CPD) to support their ongoing journey. Explicit aspirations included deepening integration with other modalities, training with spiritual support, and recapitulation of the framework.

Eliot also expressed a particular desire for WAC collaborative scrutiny and dialogue around WIFbased therapy with LGBTQ+ clients, wondering: 
'Transgender: would that be physical? Would it be about the body or is it about something much deeper about identity? If so, is that more in the spiritual area? You know you're going to get that knocking on your door.'

Self-reflection and professional discourse are encouraged by voices appealing for improvement in therapeutic services to LGBTQ+ clients (Davies \& Neal 2000; Webb, 2019). Eliot's attempts to develop and grow a WIF-practice that engages and thrives with diversity is an important and evidently pressing contemporary concern.

Clarkson's conviction that 'integration is an ongoing process in a continual state of development and evolution' (Clarkson,1992:290), was indicated in participants' hopes and expectations of future development in practice with the WIF. Looking forward evoked a range of emotions. For Dana, eager expectation was evident in the prospect of setting up an agency where 'the WIF is quite central... valuing the whole person. Wanting their wholeness, wanting their wellbeing... restoration.'

Eliot's future prospects carried an expectation of isolation. Geographical distance from the academic home of the WIF, and perceived reduced population of practitioners evoked a sense of loneliness and vulnerability:

'It's harder for you if you're geographically very distant; up North it's a bit of a Waverley wilderness, really, so there is that kind of sense of you're a bit cast adrift.'

Rønnestad \& Skovholt's findings uphold Eliot's concerns: continual support and stimulation were 'crucial' to growth and development and protected against 'stagnation and deterioration' (1992:509-10). Additionally, as an integrative practitioner, Eliot is part of an approach so varied and individual that felt-kinship between practitioners, and the benefits of an associated community, may be more indistinct and less effective at providing the support practitioners need than in single-school approaches. WIF practitioners are a 'paradigm community' (Hollanders, 1999:490) with abundant potential to confer, support and develop their own 'denominational issues' (ibid).

\section{Discussion}

This study's findings have explored the life-worlds of participants, through the interpretative lens of the researcher. Wider implications for the field are raised, with suggestions for research and practice contexts.

\section{Assimilating theory}

Incorporating the WIF into therapeutic practice starts at the level of theory. From the outset, exposure to a range of models and techniques prompts a journey of conceptualisation. Learning, selection and integration fashion a tapestry of ideas to create something that feels fit for purpose.

\section{Entanglement}

The development of an integrative approach unquestionably poses difficulties for training (Hollanders, 1999; Ginter, 1988; Gold, 2005). Kuhn's conviction that it is impossible to see the world in more than one way at a time (1970a,1970b) supports participant's experience of entanglement. Among psychotherapeutic approaches, integrationists are peculiar in facing this 
incommensurability of paradigms. Robinson et al.'s study of trainee therapists suggests there is a need to 'normalise the uncertainty which permeates the experience of trainees' (2019:396).

In this research, participants' exposure to a wealth of theory was found to produce experiences of confusion and disorientation. These are consonant with Hollanders' observations of trainees on integrative courses (1999:494), and Lowndes and Hanley's (2010) study of newly qualified integrative counsellors. In the latter, participants, struggling to tolerate 'theoretical tension', underwent 'an ambiguous and anxious process' (p169). Participants of Lowndes and Hanley's study held a different integration approach (Egan's 'Skilled Helper', 1998) preventing exact comparison to this research project but other studies (Robinson, et al., 2019; Rønnestad, et al., 2019) corroberate a compound picture of vulnerability and uncertainty as a common experience among trainee integrative counsellors (Gold, 2005).

\section{Seeking stability}

The method of levels approach (Carey et al., 2015) states that a crisis within one's standard frame of understanding provokes an equilibrating response (a reorganisation) to bring perception of one's world back into tolerable margins. For these participants, having experienced the discombobulation of theoretical overload, the WIF appeared to present an organising influence on the conflict, bringing a sense of security and confidence to their attitude towards integrating theory and establishing higher levels of perception. It would be interesting to discover whether studies with students, therapists and trainers in the WIF would produce similar findings (confusion that settles into something more stable). Research of this kind has potential to elucidate the experience for newcomers to the field and inform how trainers support it.

Hansen warns that theory construction is a means of attempting to deny the existential isolation at the subjective heart of human experience. He states:

'The hidden motive then, cloaked in the false garb of theory construction, has been to avoid confronting the inevitable isolation that subjectivity portends' (2007:123).

Additionally, Hansen states that 'people can never be fully known by theory' (2007:123); but from a Christian worldview, people can fully be known by God. In this sense, God is the definitive 'attachment figure' (Bowlby, 1969) by nature: truth, wisdom and love and the ideal 'secure base' to venture out from. It is human nature to quest for truth and engage in meaning-making. A Christian stance recognises not only phenomenon, 'the appearance of things', but also noumenon, 'thething-in-itself' (Kant, 2001). The WIF stands on the absolute - I Am - truth of God, while utilising the discovered - I perceive - truth of mankind.

The WIF's biblical presuppositions hold humankind as equal, experiential agents. The concept of free will supports a phenomenological democracy in the profoundly human search for understanding and meaning, which scripture suggests is found within a realisation of humanity's role with the divine. As Smith claims: 'truly effective counselling or psychotherapy depends on the truth derived from both the natural and the supernatural realms' (1990:180), a counselling approach that maintains an openness to both of these truth sources initiates a truly integrative process. 


\section{A spiritually secure base}

The findings indicated participants found a secure identity in the WIF. Perhaps the kind of 'focal point' Hollanders suggests is particularly needed for integrative trainees 'to be able to gain a sense of identity and commitment... where [it] is not a "given" in the same way as in single-school training' (Hollanders, 1999:488-9).

Wittgenstein's visualisation of one's 'world-picture' (or paradigm) as the hinges of a door, which remain still while the door is free to swing (1972:341), correlates with participant accounts of their life-worlds where the WIF becomes a safe place to remain while scrutiny and absorption of ideas oscillates.

The WIF's grounding in Christian scripture (Hughes, 2002; Kallmier, 2011; Ashley, 2015) begets a deep philosophy for human design, functioning and purpose. Trainees recognising and rooting themselves within these presuppositions are able to 'appraise the thinking of the secular theorists who have gone before... carefully listening to them from the perspective of the Christian tradition' (Jones and Butman, 2017:43). Participants of this study demonstrated an increased facility to engage with other modalities from the position of the WIF.

The establishment of some solid ground at a philosophical level (a certainty and surety on a level of faith and values) can be associated with Bowlby's 'secure base' (1988), which allows cultivation of an 'internal working model' for therapist self-concept, and for their concept of others. In practice, operation from a secure base fosters attitudes congruent with both common factors theory (Rozenzweig, 1936; Rogers, 1957; Luborsky, 1975; Frank, 1993), and with the WIF (Hughes, 2002; Kallmier, 2011; Ashley, 2015). Personal stability enables a 'holding environment' (Winnicott, 1965), promotes the focus and attunement needed in offering empathy, congruence and unconditional positive regard (Rogers, 1957), and increases toleration for working with uncertainty.

\section{Theory in action}

Theory assimilation cannot be divorced from practice as the two are in parallel synthesis during training. Theories of situated cognition (Gibson, (1977) and embodied cognition (Varela \& Thompson, 1991; Damasio, 1999) support assimilation within the counselling room where assorted theories, thoughts, feelings, observations and possible therapeutic interventions must tumble together in the mind of the therapist, like so many items in a washing machine.

The methods of level process of crisis and reorganisation (Carey, 2015) is in constant evidence as therapists grapple with all this alongside the maverick variable of the client - each one unique and unpredictable - who are, to some degree subject, partner and leader in the therapist's cognitive navigations, therapeutic choices and evaluations (De Stefano, et al., 2010). It has been suggested that it is the client who contextualises and is perhaps the ultimate aid to assimilating theory (Rønnestad \& Skovholt 1992:512). This must particularly apply to integrative counsellors whose decision-making about use of theory and intervention will necessarily be a responsive effort to create therapy that is 'collaborative, personal and tailored' (Lowndes, 2010:167).

The context of practice appears to propagate theory. Participants' experiences in practice indicated a process of ontogeny involved in incorporating the WIF. A journey rich in 'perceptual 
learning' (Kellman, 2002), which neurobiologists Roeder, et al, (2017) describe as experience corresponding with perception to establish a deeper learning. This study suggests that it is here that skill development flourishes, and a sense of continuity emerges while raising tolerance for change. Toren describes 'psychological structures that are at once dynamic and stable over time' as arising from 'the meaning or knowledge-making process' (2002:190).

Contextualising theory through practice is a proven method of practitioners developing skill and identity. (Strupp, 1986; Mezirow, 1990; McLeod. J., 2014; Rønnestad et al. 2003; Rønnestad \& Skovholt, 2013, 2019; Kolb, 1975). Hansen has stated that: 'Without guiding theories, counselling could not possibly be effective. On the other hand, without an appreciation for the rich and contradictory nature of subjectivity, attempts to understand clients would be futile' (2007:123).

Clinical practice was shown here to be an important arena for deep assimilation and discerning application of the WIF. Its incorporation into a personal approach involved conceptualisation, intuition and decisiveness, suggesting many levels of understanding and learning take place within the therapy room. Similar experiences of 'transformational learning' (Mezirow, 1990) have been observed in trainees on other courses involving; 'reflection... awareness, internalisation and selfdevelopment' (Robinson, et al., 2019:397).

\section{Organic not orchestrated}

In this study, perceptions of rigidity within training did not appear to correlate to how the WIF feels in practice. Participants observed it became fluid rather than fixed, organic rather than an orchestrated process. Descriptions of thoughtful interaction of the WIF alongside freedom and creative engagement in the process of making choices, selecting ideas and interventions, harmonised with extant literature: 'When applying the Waverley model to the therapeutic process, many variations of personal style and practical interventions are possible, and also desirable to avoid an overly rigid application' (Ashley, 2015:147).

This kind of nuance develops once a foundation is laid. The appraisal and critique expressed by participants testifies to their development; the WIF theory they remember as fairly rigid and fixed, has since become a living and learning process; a developed and dynamic skill.

WIF scholars are clear about avoiding 'ways of being with clients [that] can become habitual for the psychotherapist and, possibly over-constrained by the ways they were taught' (Hawkins and Ryde, 2020:29). Hughes (in Ashley, 2015:127), Kallmier $(2011: 73,124,133,136,206)$ and Ashley $(127,128,131,132,140$,$) have all advised against formulaic application of the Framework. WIF$ adherents are encouraged to use the 'framework of principles... creatively applied according to context' practising it 'as an 'art' not as 'science'.' (Ashley, 2015:131). While Kallmier's triphasic system demonstrates 'clear and helpful procedure for people beginning counselling', flexibility and client-specific appropriacy are advised in practice, to avoid the 'real danger of the steps becoming a formula that must be followed' (Kallmier, 2011:136).

It is curious therefore, that participants across this study expressed frustration with a sense of taught rigidity that they had made fluid within practice. This attitude has also been perceived anecdotally by the researcher, where fellow trainees with similar criticisms have sometimes deemed the WIF too rigid for practice. No approach is comfortable or desirable for everyone, but 
perhaps further exploration of WIF teaching and learning experience might expose where confusion or discrepancy might lie and reduce disenchantment with the WIF where it is based on misunderstanding. This kind of research has potential to inform delivery of the WIF and foster a clearer understanding of flexible implementation.

\section{Authentic practitioners}

Participants described feelings of authenticity, freedom and enablement in bringing an approach that incorporated their faith beliefs to a field where it was felt that couldn't be taken for granted.

Rogers' direction that a therapist must be 'a congruent, genuine, integrated person' (1957:95) resonated strongly with the sense of self that was described. Steele goes further, asserting that a spiritually-attuned therapist presents the most complete version of themselves and has the most to offer others (2014:12). Participants' subjective identification with the personhood described by the WIF correlates strongly with Steele's advocation that therapists be spiritually 'at home' in themselves: 'congruent... authentic, real and natural in our relationship with the client ... not hiding behind a defensive mask... or a professional role' (Steele, 2014:149-50).

While a congruent spirituality is a valuable therapeutic resource, it is critical that therapists of faith scrutinise their practice if they are to work with professionalism and integrity (West, 2000; Barnett,\& Johnson, 2011; Gonsiorek et al., 2009). Steele reminds 'it can also be a source of resistance which impedes the therapeutic process and may even sabotage our growth and healing' (Steele, 2014:180). Careful adherence to ethical frameworks for counselling (BACP, 2018; ACC, 2004) and use of religious and spiritual competency frameworks (Churchill, 2021a; Hathaway, 2013) could mitigate this. A growing discussion exists around spiritual congruency in therapy, (Thorne, 1991; Edwards, 1992; Elkins, 1995; Swinton, 2001; West, 2012; Swinton, 2016) which is beyond the scope of this paper.

Research by Omylinska-Thurston and James, also determined that the practice of congruency requires 'therapists to have a high level of self-awareness and internal discipline in order not to 'act-out' and misuse power in the therapeutic relationships' (2011:20). Wyatt agrees: 'When I am clear about my faith and comfortable with it... what I believe... what my values are, or I know that I don't know. Then, when I am like that, I can listen to clients' (2002:182).

\section{More than a diagram}

The diagram at the heart of the WIF has three renderings. This research has shown it had a role to play in participant experiences of incorporating the WIF into practice; an anchor-point for the novice seeking synthesis between psychological and theological foundations; a tool to impart to clients their holistic personhood and a therapeutic way of working. Participants also showed enthusiasm about utilising it as a clinical tool. An intervention with multiple uses.

These experiences are supported by Boisvert \& Ahmed (2018), instigators of visually enhanced therapy (VET), who argue that the visually-oriented human brain processes seen-stimuli in a way that 'augment[s] the communication platform and learning environment in psychotherapy' (p3). Participants' successful use of the diagram corroborates this researcher's experiences of its therapeutic potency. Other approaches (notably CBT) use diagrams in more central and interactive ways within therapy. Arguably, the WIF diagram has as much accessibility, with a more holistic 
Working with the Waverley integrative framework: Exploring the experience of counsellors, trained in the Waverley integrative framework (WIF), in incorporating the framework into their therapeutic practice.

Charlotte Wears

application. Engagement with VET in working with the WIF may have potential within this visual age.

\section{A sense of becoming}

As Robinson et al (2019) suggest, the maturity of a therapist is not purely a matter of being clinically competent, it is wholly interrelated with personal development. This study revealed an experience of 'becoming' among participants that has strong resonance with the findings already mentioned in Armitage's study of WIF students (2018). Robinson et al's study of Australian trainees also reported 'growth... both personally and professionally... a journey, which included both negative and positive aspects and expectation of future transitions' (p394). However, both studies sampled single cohorts of counselling trainees so lack close parallel with this study's qualified and experienced sample.

Williams \& Irving (1996) suggest true personal development will go 'beyond the mere "state of knowing", implied by self-awareness, to encompass an individual's whole "way of being"' (in Donati \& Watts 2005:482). Participants in this study described a comparable experience of 'becoming' by its very nature implying an encompassing and ongoing state. By definition, integrative therapists must consistently be inter-weaving learning and experience. Dryden (1991), Clarkson (1992), and Hollanders, (1999) - all veterans in teaching, working and researching within the field - ratify this finding: an integrative approach that feels competent demands considerable time, personal commitment and accumulated experience.

\section{Leaving and returning}

A theme of leaving and returning to the framework emerged, which this researcher has not discovered explicitly within extant literature. However, Rønnestad et al, (2019) found 'cyclicalsequential' development trajectories within a meta-study that gathered qualitative and quantative data from a sample of therapists with a diverse range of experience. Similarly, in implementing educational psychologist Perry's (1970) model of college students' development, Prochaska (1986:388-411) describes and illustrates phases of therapist progress until finally entering a 'committed' stage. It is possible that both sources describe factors within or impacting this 'leaving and returning process; indeed, it is possible these are alternate interpretations of similar experiences.

\section{WIF ontogenesis: A circle of learning}

The participants, all 'established' or 'seasoned' therapists (Rønnestad et al, 2019:223), appeared settled, comfortable and creative when talking about their present practice. Like a flowering plant, there was a sense of being the thing one is destined to be: well-rooted, somewhat hardy and carrying the potential to proliferate.

Giovazolias found that 'developing as an integrative practitioner, one needs to draw on these three aspects (theory, research and practice) using the knowledge derived to tailor therapy to the client's needs' (2005:162). Through personal reflection on clinical practice he felt able to 'practise more integratively... [and to] ceaselessly continue to build a practical model based on a combination of theory and technique that fits [his] own values and assumptions' (2005:165-7). The illustration of 
a symbiotic and sustaining circle formed by the disciplines of theory, practice and research is pertinent and his reflective method is one that could have future application for WIF research.

Meara et al encourage therapists to 'recognise[s] the interdependence of theory, research and practice' (1988:368). If theory finds expression in practice, then its recollection and reflection form an important aspect of research. This can generate an augmenting spiral where mounting experience increases understanding, Hansen observes: 'the next logical step in the method, in hermeneutic circular fashion, would be for the experiential phenomena revealed by the method to inform subsequent theory construction and so on' (2007:122).

This study has demonstrated the interactivity and interdependence between the spheres of psychotherapeutic theory, practice and research. Shakow's 'scientist-practitioner model', (or the boulder model) (in Frank, 1984) advocates such intersubjectivity and cumulative understanding. As cross-pollination creates multiple benefits in the natural world, so these disciplines are in need of each other's participation. Goldfried and Padawer have pronounced that 'for the researcher and clinician to ignore the contributions that each has to make is to perpetuate a system in which no one wins' (Goldfried \& Padawer, 1982:33). By converse reasoning, there is rich potential for advancement where they co-operate.

Stiles assertion that 'Practitioners, not researchers, are the main producers of research ideas' (in Lampropoulos, et al., 2002:1253) is demonstrated in this study. That 'most approaches [are] practised long before they [are] formally researched' (ibid) is evidenced in publications about the framework (Hughes, 2002; Kallmier, 2011). This researcher suggests the time is ripe to explore the diverse extant expressions of the framework.

\section{Therapist cumulative and collective experience}

Further studies conducted with integrative practitioners are in demand, from those with trainee status (Robinson, et al., 2019), right through to mature therapists (Lampropoulos, et al., 2002; Rønnestad et al. 2019). The ongoing SPRISTAD study (Society for Psychotherapy Research, 2011) has potential to deliver information on therapist ontogenesis that may inform and enable enhancement of therapist training and development for teachers, students and therapists working with the WIF.

If the shared wisdom of therapists using the framework can be compared to the cross-pollination and fruiting of mature plants, the potential 'seed' (e.g., collaboration, dialogue, invigoration, refinement) benefits individual practitioners and the wider WIF community. The rich, diverse experience with the framework is research that informs future theory and practice, with even fallen leaves of failure fertilising the seedbed. Castonguay's suggestion to establish practice research networks (PRN's) may be a step towards facilitating this 'cyclical and reciprocal relationship between therapeutic practice and development' (Rønnestad, et al., 2019:226).

It is suggested that the triad of theory, practice and research are the life-cycle at the heart of a growing psychotherapeutic community. WIF practitioners have the cumulative experience to consult on practice and learn from research. Gathered around a shared foundational philosophy, they are a 'paradigm community' (Hollanders, 1999:490), where identity, commitment and credibility can grow. 


\section{Recommendations}

As has been stated, the WIF is almost entirely unresearched. Consequently these suggestions are a fraction of what is conceivable.

The three themes produced in this study each have potential to be subjected to deeper study alone. Reflexive suggestions arising from these include: consideration of the WIF diagram within the counselling room; attentiveness to how the framework is taught, rehearsed and applied; exploration of the appetite for continuing professional development (CPD) with the framework, including the focused hopes and ideas arising directly from this sample (such as integration with modalities, supervision, spiritual support, therapist refreshment of the framework and working with LGBTQ+ clients).

Looking beyond IPA, it is suggested that a combination of research methods might ideally provide a richer base of knowledge. Lampropoulos et al., advocate for the benefits of case studies (2002:1245), and Parrow, et al., (2019) encourage the collection of practice-based evidence. Feedback from clients who have experienced WIF-informed practice would likely be enlightening.

Integrative counsellors appear to benefit enormously from reflective practice (Giovazolias, 2005; Finlay, 2016). This researcher believes that the reflective writing of WIF trainees (already a curricular requirement), and from practitioners would be valuable to the framework's community of practitioners, particularly, as has been shown, in informing every stage of therapist ontogenesis. The British Journal of Psychotherapy Integration consistently carries self-articulated accounts of therapists evolving personal approaches - a practice that might have potential in aiding therapists working with the WIF. Possible potential may also lie in something akin to Castonguay's proposed PRN's (in Lampropoulos et al., 2002:1253).

\section{Conclusion}

This research responds to the invitations of Kallmier, (2011:205), Ashley, (2015:127-128) and Armitage, (2018:67) for further investigation and development of the WIF. The journey towards maturity has been described here as a process of ontogenesis; begun in perplexity and brought to embodiment. In the mind of the researcher, an emergent visual accompaniment to this study has compared the WIF to soil that nurtures a germinating seed, supports its growth and sustains the mature plant rooted deeply within it. This researcher has come to believe that therapists hold the framework and the framework holds them. 
Working with the Waverley integrative framework: Exploring the experience of counsellors, trained in the Waverley integrative framework (WIF), in incorporating the framework into their therapeutic practice.

\section{Reference list}

ACC, (2004) ACC Ethics and practice. [Online]

Available at: https://www.acc-uk.org/public/docs/page-pdfs/EandPractice.pdf

[Accessed 1 July 2021].

American Psychological Association (APA), (2007). Getting in. Washington, American Psychological Association.

Armitage, S. (2018) What is the Impact of the Waverley integrative framework on First Year Counselling students? (unpublished thesis).

Ashley, O. (2015) The Bible, Wisdom and Human Nature: Developing the Waverley Model of Counselling. Farnham: CWR.

Ashley, O. (2017) 'What's in a Model? The Bible, Wisdom and Human Nature: Developing the Waverley Model of Counselling', in Accord, 96, (Autumn), pp. 16-19.

Association of Christian Counsellors, (ACC) 2004. Ethics and Practice. [Online] Available at: https://www.acc-uk.org/public/docs/page-pdfs/EandPractice.pdf [Accessed 16th April 2020].

Barnett, M. (2007) 'What brings you here? An exploration of the unconscious motivations of those who choose to train and work as psychotherapists and counsellors', in Psychodynamic Practice: Individuals, Groups and Organisations, 13, (3), pp. 257-274.

Barnett, J. E. \&. Johnson. W. B. (2011) 'Integrating spirituality and religion into psychotherapy: Persistent dilemmas, ethical issues, and a proposed decision-making process', Ethics \& Behavior, 21, (2), pp. 147-164.

Beitman, B. \&. Yue, D. (1999) Learning psychotherapy: A timeefficient, research-based, and outcomemeasured psychotherapy training program, New York: WW Norton and Company.

Boisvert, C. \& Ahmed, M. (2018) Using diagrams in Psychotherapy, Abingdon: Routledge.

Bond, T. (2004) Ethical Guidelines for Research Counselling and Psychotherapy, London: BACP.

Bond, T. (2000) 'Bond's Pond.' In: Palmer, S. \&. Woolfe, R. (eds) Integrative and Eclectic Counselling and Psychotherapy, London: Sage, p. 319.

Bowlby, J. (1969) Attachment and Loss: vol 1 Loss, New York: Basic Books.

Bowlby, J. (1988) A Secure Base: Clinical Applications of Attachment Theory, London: Routledge.

British Association for Counselling and Psychotherapy. (2017) Good Practice in Action 044 Fact Sheet Ethical decision making in the context of the counselling professions. Lutterworth: BACP.

British Association for Counselling and Psychotherapy. (2018) BACP Ethical Framework for the counselling profession.

[Online] 
Available at: https://www.bacp.co.uk/media/3103/bacp-ethical-framework-for-the-counsellingprofessions-2018.pdf

[Accessed March 2020].

British Association of Counsellors and Psychotherapists. (2019) Ethical Guidelines for Research in the Counselling Professions. [Online] Available at: https://www.bacp.co.uk/media/3908/bacp-ethical-guidelines-for-research-incounselling-professions-feb19.pdf

[Accessed 10th December 2020].

Carey, T. A.; Mansell. W.; Tai. S. (2015) Principles-based counselling and psychotherapy: a method of levels approach.. London; New York: Routledge.

Castonguay, L. G. (2006) 'Personal pathways in psychotherapy integration' in Journal of Psychotherapy Integration, 16, pp. 36-58.

Castonguay, L. G.; Goldfried. M. (1994) 'Psychotherapy integration: An idea whose time has come', in Applied and Preventive Psychology, 3, (3), pp. 159-172.

Cheston, S. E. (2000) 'A New Paradigm for Teaching Counseling Theory and Practice', in Counselor Education and Supervision: vol 39, (4), pp. 254-270.

Churchill, H. (2021) email exchange with researcher

Churchill, H. (2021) The Churchill Framework. [Online] Available at: https://www.acc-uk.org/public/docs/The Churchill Framework.pdf

Clarkson, P. (1975) Seven Epistemological Level,. Pretoria, SA: University of Pretoria.

Clarkson, P. (1992) 'Systematic integrative psychotherapy training'. In: Integrative and Eclectic Psychotherapy: A Handbook. Buckingham: Open University Press.

Clarkson, P. (2003) The Therapeutic relationship, (2nd ed.) London: Whurr publishers.

Clebsch, W. A.; Jaekle. C. R. (1975) Pastoral Care in Historical Perspective, (3rd ed.) New York: J. Aronson.

Cooper, M. (2008) Essential Research Findings in counselling and psychotherapy, London: Sage.

Cooper, M. \& McLeod, J. (2010) Pluralistic counselling and psychotherapy. London: Sage.

Corey, G. (1995) Theory and Practice of Counselling and Psychotherapy, (5th ed.) Pacific Grove: Brooks/Cole.

Corsini, R. J. \& Wedding. D. (1989) Current Psychotherapies, Itsaca: peacock.

Cozolino, L. (2004) The Making of a Therapist, New York: Norton.

Crabb, L. (1977) Effective Biblical Counseling: a Model for Helping Caring Christians Become Capable Counselor, Grand Rapids: Zondervan. 
Working with the Waverley integrative framework: Exploring the experience of counsellors, trained in the Waverley integrative framework (WIF), in incorporating the framework into their therapeutic practice.

Charlotte Wears

Crabb, L. (1987) Understanding People: Deep Longings for Relationship, Grand Rapids: Zondervan.

Crabb, L. (1997) Connecting: Healing for Ourselves and our Relationships, Nashville: W. Publishing Group.

Damasio, A. (1999) The Feeling of What Happens: Body and Emotion in the Making of Consciousness, New York: Houghton Mifflin Harcourt.

Davies, D. \& Neal. C. (2000) Therapeutic Perspectives on Working with Lesbian, Gay and Bisexual Clients, Buckingham: Open University Press..

De Stefano, J.; Mann-Feder, V. \& Gazzola, N. (2010) 'A qualitative study of client experiences of working with novice counsellors,' in Counselling and Psychotherapy Research, 10, (2), pp. 139-146,.

Donati, M. \& Watts. M. (2005) 'Personal development in counsellor training: towards a clarification of inter-related concepts', in British Journal of Guidance \& Counselling, 33, (4), pp. 475-484.

Dryden, W. (1991) A Dialogue with John Norcross: Towards Integration, Milton Keynes: Open University Press.

Duncan, B. L., Miller, S.D, Sparks, J.A. (2004) The Heroic Client, San Francisco: Jossey-Bass.

Edwards, G. (1992) Does psychotherapy need a soul? In Dryden, W. and Feltham, C.W. (eds), in Psychotherapy and its discontents, Buckingham: Open University Press. pp. 194-224.

Egan, G. (1998) The Skilled Helper, (6th ed). Pacific Grove: Brooks/Cole.

Elkins, D. N. (1995) 'Psychotherapy and spirituality: Toward a theory of the soul', Journal of Humanistic Psychology, 35, pp. 78-99.

Erikson, E. H. (1980) Identity and the Life Cycle, Oxford: International Universities Press.

Eysenck, H. J. (1970) A mish-mash of theories. International Journal of Psychiatry, 9, pp. 140-146.

Finlay, L. (2016) Relational Integrative psychotherapy: Engaging Process and Theory in Practice. Malden: Wiley.

Fonagy, P., Gergely, G., Jurist, E. L. \& Target, M. (2002) Affect Regulation, Mentalization, and the Development of the Self. New York: Other Press.

Fouque, P. \&. Glachan. M. (2000) 'The impact of Christian counselling on survivors of sexual abuse.' in Counselling Psychology Quarterly, 13, (2), pp. 201-220.

Frank, G. (1984) 'The Boulder model: History, rationale, and critique', in Professional Psychology: Research and Practice, 15, (3), pp. 417-435.

Frank, J. D. \&. Frank. J. B. (1993) Persuasion and Healing: A comparative study of psychotherapy, (3rd ed) Baltimore: Johns Hopkins Uiniversity Press.

Frankl, V. E. (1946/2004) Man's Search for Meaning, London: Rider. 
Working with the Waverley integrative framework: Exploring the experience of counsellors, trained in the Waverley integrative framework (WIF), in incorporating the framework into their therapeutic practice.

Garfield, S. L. (1980) Psychotherapy: An Eclectic Approach, New York: Wiley.

Gergen, K. (2009) Relational being: Beyond self and community, New York: Oxford University Press.

Gibson, J., (1977) 'The Theory of Affordances', in: Bransford, R. Shaw, J. (ed.) Perceiving, Acting, and Knowing: Toward an Ecological Psychology. Hillsdale: Lawrence Erlbaum, pp. 67-82.

Giddens, A. (1993) New Rules of Sociological Method: A Positive Critique of Interpretative Sociologies, (2nd ed.) Stanford: Stanford University Press.

Gilbert, P. (2019) 'Psychotherapy for the 21st century: An integrative, evolutionary, contextual, biopsychosocial approach', in Psychology \& Psychotherapy: Theory, Research \& Practice, 92, (2), pp. 164-189.

Ginter, E. J. (1988) 'Stagnation in eclecticism: The need to recommit to a journey', in The Journal of Mental Health Counselling?, 10, pp. 3-8.

Giovazolias, T. (2005) 'Counselling Psychology and the Integration of Theory, Research and Practice: A Personal Account', in Counselling Psychology Quarterly, 18, (2), pp. 161-168.

Gold, J. (2005) 'Anxiety, conflict, and resistance in learning an integrative perspective on psychotherapy.' in Journal of Psychotherapy Integration, 15, (4), pp. 374-383.

Goldfried, M. R. \&. Castonguay. L. G. (1992) 'The future of psychotherapy integration', in Psychotherapy: Theory, Research, Practice, Training, 29, (1), pp. 4-10.

Goldfried, M. R. \& Padawer, W. (1982) 'Current status and future directions in psychotherapy'. in Converging Themes in Psychotherapy: Trends in psychodynamic, humanistic, and behavioral practice, New York: Springer, pp. 3-49.

Gonsiorek, J. C. Richards. P. S. Pargament. K. I. \&. McMinn. M. R. (2009) 'Ethical challenges and opportunities at the edge: Incorporating spirituality and religion into psychotherapy', Professional Psychology: Research and Practice, 40, (4), p. 385- 395.

Grawe, K. (2004) Psychological therapy, Seattle: Hogrefe \& Huber.

Grencavage, L. M. \&. Norcross. J. C. (1990) 'Where are the commonalities among the therapeutic common factors?' in Professional Psychology: Research and Practice, 21, pp. 372-378.

Guntrip, (1969) 'Religion in Relation to Personal Integration', in British Journal of Medical Psychology, 42, pp. 323-333.

Hansen, J. T. (2007) 'Epistemic Contradictions in Counseling Theories: Implications for the Structure of Human Experience and Counseling Practice.' in Counseling and Values, 51, (2), pp. 111-124.

Harrison, G. (2017) Psycho-Spiritual Care in Health Care Practice (ed.) London: Jessica Kingsley.

Hathaway, W. (2013) 'Pathways toward graduate training in the clinical psychology of religion and spirituality: A spiritual competencies model.' In: K. I. Pargament, (ed.) Handbook of Psychology, 
Working with the Waverley integrative framework: Exploring the experience of counsellors, trained in the Waverley integrative framework (WIF), in incorporating the framework into their therapeutic practice.

Charlotte Wears

Religion and Spirituality: Vol 2. An Applied Psychology of Religion and Spirituality, Washington: APA, pp. $635-650$

Hawkins, P. \& Ryde. J. (2020) Integrative Psychotherapy in Theory and Practice: A relational, Systemic and Ecological Approach, London: Jessica Kingsley.

Hay, D. \&. Hunt. K. (2000) Understanding the spirituality of people who don't go to church, Nottingham: Centre for the study of human relations, Nottingham University.

Heidegger, M. ( 2002) Heidegger: Off the Beaten Track.. Cambridge: Cambridge University Press.

Hess, A. K., Hess, K. D. \& \& Hess, T. H. (2008) Psychotherapy supervision: Theory, research, and practice, Hoboken: John Wiley \& Sons.

Hillman, J. (1975) Re-visioning Psychology, New York: Harper\& Row.

Hollanders, H. (1999) 'Eclecticism and integration in counselling: implications for training.' in British Journal of Guidance \& Counselling, 27, (4), pp. 483-500.

Hollanders, H. (2000) "Eclecticism/integration: Some key issues and research"; in Integrative and eclectic counselling and psychotherapy. London: Sage, pp. 31-56.

Hough, M. (2014) Counselling Skills and Theory. (4th ed.) Abingdon : Bookpoint Ltd.

Howard, E., Inman, A. \& Altman, A. (2006) 'Critical incidents among novice counselor trainees.' in Counselor Education and Supervision, 46, (2), pp. 88-102.

Hughes, S., (1981) How to Help a Friend, Eastbourne: Kingsway.

Hughes, S. (2002) Christ Empowered Living, Farnham: CWR.

Hughes, S. (2004) My Story. Farnham: CWR.

Hunsley, J. \& Di Guiilo. G. (2002) 'Dodo Bird, Phoenix, or Urban Legend?, in Scientific Review of Mental Health Practices, 1, (1), pp. 11-22.

Hurding, R. (2003) Roots and Shoots: A Guide to Counselling and Psychotherapy, 2nd ed London: Hodder and Stoughton.

Husserl, E., (1936/1970). The Crisis of the European Sciences, (2nd ed), Evanston: North Western University Press.

Irving, J. \&. Williams. D. (1999) Personal growth and personal development: concepts clarified, in British Journal of Guidance and Counselling, 27, (4), pp. 517-526.

Jones, S. L. \& Butmam. R. (2017) Modern Psychotherapies Hardback A Comprehensive Christian Appraisal, US: Inter-Varsity Press.

Jung, C. G. (1953) Collected works. Vol. 12: Psychology and alchemy, New York: Pantheon Books. 
Working with the Waverley integrative framework: Exploring the experience of counsellors, trained in the Waverley integrative framework (WIF), in incorporating the framework into their therapeutic practice.

Kallmier, R. (2011) Caring and Counselling, Farnham: CWR.

Kant, I. (2001) Prolegomena to Any Future Metaphysics, 2nd ed. Cambridge, MA: Hackett Publishing.

Kegan, R. (1994) In Over Our Heads: the Mental Demands of Modern Life, Cambridge, MA: Harvard University Press.

Kellman, P. J. (2002) "Perceptual learning", in Pashler, H. \& Gallistel, R. (eds) Stevens' Handbook of Experimental Psychology. 3: Learning, Motivation, and Emotion, New York: Wiley, pp. 259-301.

Kolb, D. A. \&. Fry. R. (1975) 'Toward an applied theory of experiential learning', In: G. Cooper, (ed.) Theories of Group Process, New York: Wiley, pp. 33-57.

Kreeft, P. (1990) Summa of the Summa, San Francisco: Ignatius press.

Kuhn, T. S., (1970a.) The Structure of Scientific Revolutions, Chicago: University of Chicago Press.

Kuhn, T. S. (1970b) 'Reflection on my critics', In: I. \&. M. A. Lakatos, (ed.) Criticism and the Growth of Knowledge: Proceedings of the International Colloquium in the Philosophy of science, New York: Cambridge University Press.

Kvale, S. (1992) Psychology and Postmodernism, London: Sage.

Lambert, M. J. (1992) 'Implications of outcome research for psychotherapy integration', in Goldstein, J. C. \& Norcross, M. R. (eds.) Handbook of psychotherapy integration, New York: Basic Books, pp. 94-129.

Lampropoulos, G. K.; Goldfried, M. R.; Castonguay, L. G.; Lambert, M. J.; Stiles, W. B.; Nestoros, J. N. (2002) 'What kind of research can we realistically expect from the practitioner?' in Journal of clinical psychology, 58, (10), pp. 1241-1264.

Lapworth, P.; Sills, C. \&. Fish. S. (2001) Integration in Counselling \& Psychotherapy, London: Sage.

Lazarus, A. A. (1981) The Practice of Multimodal Therapy, New York: McGraw-Hill.

Lecomte, C.; Castonguay, G.; Cyr, M.; \& Sabourin, S. (1993) 'Supervision and instruction in doctoral psychotherapy integration' in: Gold, G. \& Stricker, R.G. (ed.) Comprehensive handbook of psychotherapy integration, New York: Plenum.

Lovelace, R. (1979) Dynamics of Spiritul life: An Evangelical Theology of Renewal, Downers Grove: Intervarsity Press.

Lowndes, L. \& Hanley. T. (2010) 'The challenge of becoming an integrative counsellor: The trainee's perspective', in Counselling and Psychotherapy Research, 10, (3), pp. $163-172$.

Luborsky, L.; Singer, B. \& Luborsky, L. (1975) 'Comparative Studies of psychotherapies: Is it true that "everyone has won, all must have prizes"?', in Archive of General Psychiatry, 32, pp. 995-1008. 
Luborsky, L.; Seligman, D. A.; Rosenthal, R.; Krause, E. D.; Johnson, D.; Halperin, G.; Bishop, M.; Berman, J. \& Schweizer, E. (1999) 'The researcher's own therapy allegiances: A "wild card" in comparisons of treatment efficacy', in Clinical Psychology: Scientist Practitioner, 6, pp. 95-106.

Luca, M.; Marshall, C. \& Nuttall. J. (2019) Integrative Theory and Practice in Psychological Therapies: New Directions, London: McGraw-Hill, OUP.

Marks, S. (2017) 'Psychotherapy in historical perspective', in History of the human sciences, 30, (2), pp. 3-16.

Maslow, A. (1999) Toward a Psychology of Being, 3rd ed. New York: Wiley and Sons.

McLeod. J. \&. McLeod. J. (2014) Personal and Professional Development for Counsellors, Psychotherapists and Mental Health Practitioners, Maidenhead: Open University Press.

McLeod, J. (2018) An Introduction to Counselling and Psychotherapy: Theory, Research and Practice, New York: McGraw-Hill/OUP.

McMinn, M. R. \& Campbell C. (2007) Integrative Psychotherapy: Towards a Comprehensive Christan Approach, Wheaton: IVP.

Meara, N. M.; Schmidt, L. D.; Carrington, C.H. \& Davis, K. L. (1988) 'Training and Accreditation in Counselling Psychology', in The Counselling Psychologist, 16, (3), pp. 366-384.

Mearns, D. (1997) Person-Centred Counselling Training, London: Sage.

Mezirow, J. (1990) How critical reflection triggers transformative learning, San Francisco: Jossey-Bass.

Moore, T. (1992) Care of the Soul, London: Piatkus.

Nel, P. W.; Pezzolesi, C. \& and Stott, D. J. (2012) 'How Did We Learn Best? A Retrospective Survey of Clinical Psychology Training in the United Kingdom', in Journal of Clinical Psychology, 68, (9), pp. 1058-1073.

Norcross, J. C. \& Goldfried, M. R. (2003) Handbook of Psychotherapy Integration, New york: Oxford university Press.

Norcross, J. C.; Pfund, R. A.; \& Prochaska, J. O. (2013) 'Psychotherapy in 2022: A Delphi poll on its future', in Professional Psychology: Research and Practice, 44, (5), pp. 363-370.

Nuttall, J. (2008) 'The integrative attitude-a personal journey', in European Journal of Psychotherapy \& Counselling, 10, (1), pp. 19-38.

Olthuis, J. (2006) The Beautiful Risk, Eugene: Wipf and Stock.

Omylinska-Thurston, J. \& James, P. E. (2011) 'The therapist's use of self: A closer look at the processes within congruence', in Counselling Psychology Review, 26, (3), pp. 20-33. 
Working with the Waverley integrative framework: Exploring the experience of counsellors, trained in the Waverley integrative framework (WIF), in incorporating the framework into their therapeutic practice.

Charlotte Wears

Orlinsky, D. E.; Botermans, J. F. \& Rønnestad, M. H. (2001) 'Towards an empirically grounded model of psychotherapy training: Four thousand therapists rate influences on their development', in Australian Psychologist, 36, (2), pp. 139-148.

Pargament, K. I. (2007) Spiritually Integrated Psychotherapy: Understanding and Addressing the Sacred, New York: Guilford Press.

Pargament, K. I. (2011) Spiritually Integrated Psychotherapy: Understanding and Addressing the Sacred, New York: Guilford Press.

Parrow, K.; Sommers -Flanagan, J.,;Sky Cova, J. \& Lungu, H.(2019) 'Evidence-based Relationship factors: A New Focus for Mental Health Counselling Research, Practice and Training', in Journal of Mental Health Counselling, 41, (4), pp. 327-342.

Patterson, C. (1987) 'Comments', Personality Centred Review, 1, pp. 246-248.

Paul, G. (1967) 'Strategy of Outcome Research in Psychotherapy', in Journal of Consulting Psychology, 53, (6), pp. 846-51.

Perry, W. G. (1970) Forms of intellectual and ethical development in the college years: A scheme, New York: Holt, Rinehart and Winston.

Powers, W. T. (1973) Behavior: The control of perception, Chicago: Aldine de Gruyter.

Poznanski, J. J. \&. McLennan. J. (1995) 'Conceptualizing and measuring counselors' theoretical orientation', in Journal of Counseling Psychology, 42, pp. 411-422.

Prochaska, J. O. (1986) Systems of Psychotherapy: A Transtheoretical Analysis, Homewood IL: Dorsey.

Rønnestad, H. H. \&. Skovholt. T. M., (1992) 'Themes in Therapist and Counselor Development', Journal of Counseling \& Development, 70, (4), pp. p505-515.

Rønnestad, H. H. \&. Skovholt. T. M. (2003) 'The journey of a counsellor and therapist: research findings and perspectives on professional development', in Journal of Career Development, 30, pp. 5-44.

Rønnestad, M. H. \&. Skovholt. T. M. (2013) The developing practitioner: growth and stagnation of therapists and counsellors, New York: Wiley.

Rønnestad, M.H.; Orlinsky, D.E.; Schröder, T. A.; Skovholt, T. M. \& Willutzki, U. (2019) 'The professional development of counsellors and psychotherapists: Implications of empirical studies for supervision, training and practice', in Therapists and Knowledge, 19, (3), pp. 214-230.

Ratliff, R. (2017) Richard L. Ratliff. [Online] Available at: https://hellopoetry.com/richard-lratliff/poems/ [Accessed July 2021].

Rennie, D. (2000) 'Aspects of the client's conscious control of the psychotherapeutic process', in Journal of Psychotherapy Integration, 10, pp. 151-167. 
Richards, P. \&. Bergin. A. E. (1997) A Spiritual Strategy for Counseling and Psychotherapy, Washington: APA.

Richards, P. S. \&. Worthington. E. L. Jr. (2010) 'The need for evidence-based, spiritually oriented psychotherapies', in Professional Psychology: Research and Practice, 41, (5), pp. 363-370.

Richards, P. S. \& Bergin. A. E. ( 2005) Handbook of Psychotherapy and Religious Diversity, Washington DC: American Psychological Association.

Rihacek, T. \&. Roubal. J. (2017) 'The proportion of integrationists among Czech psychotherapists and counselors: a comparison of multiple criteria' in Journal of Psychotherapy Integration, 27, pp. $13-22$

Robinson, N. L., Schweitzer, R. \& O'Connor, E. (2019) 'Early reflections on becoming a therapist: Development of reflective practice in clinical training programmes in an Australian context', in Counselling and Psychotherapy Research, 19, (4), pp. 388-398.

Roeder, J., Maddox, W. T. \& Fiolteo, J. V. (2017) 'The Neuropsychology of Perceptual Category Learning', in LeFebvre, H. \& Cohen, C. (eds.) Handbook of categorization in cognitive science, Kidlington: Elsevier, pp. 189-225.

Rogers, C. (1951) Client-Centred Therapy: Its Current practice, Implications and Theory, London: Constable.

Rogers, C. (1961) On Becoming a Person: A Therapist's view of Psychotherapy, London: Constable.

Rogers, C. (1980) A Way of Bein,. New York: Houghton Mifflin.

Rogers, C. R. (1957) 'The Necessary and Sufficient Conditions of Therapeutic Personality Change', the Journal of Consulting Psychology, 21, pp. 95-103.

Rose, S. (2010) 'Hans Eysenks controversial career', in The Lancet, 376, (9739), pp. 407-408.

Rowan, J. (1993) 'The Transpersonal: Spirituality in Psychotherapy and Counselling', London: Routledge.

Rozenzweig, S. (1936) 'Some Implicit Common Factors in Diverse Methods of Psychotherapy: 'At last the Dodo said everybody has won and all must have prizes' ', in American journal of Orthopsychiatry, 6, pp. 412-15.

Samuels, A. (1991) 'Pluralism and Training.', in Journal of the British Association of Psychotherapists, 22, pp. 3-17.

Schleiermacher, F. (1998) Hermaneutics and Criticism and Other writings, Cambridge: CUP.

Schottenbauer, M. A., Glass, C. R., Arnkoff, D. B. (2005) 'Outcome Research on Psychotherapy Integration', in Norcross, J. C. \& Goldfried, M. R. (eds.) Handbook of Psychotherapy Integration, New York: Oxford University Press, pp. 459-493. 
Working with the Waverley integrative framework: Exploring the experience of counsellors, trained in the Waverley integrative framework (WIF), in incorporating the framework into their therapeutic practice.

Charlotte Wears

Seager M, Orbach S, Samuels A, Sinason V, Johnstone L, Fredman G. (2012) Towards proactive policy: five universal psychological principles, National Advisory Group on Mental Health, Safety and Wellbeing: unpublished paper.

Sharf, R. (1996) Theories of Psychotherapies and Counseling, Pacific Grove: Brooks/Cole.

Siegel, D. J. (2010) Mindsight: The New Science of Personal Transformation, New York: Bantam.

Siegel, D. J. (2019) 'The mind in psychotherapy: An interpersonal neurobiology framework for understanding and cultivating mental health', in Psychology and Psychotherapy: Theory, Research and Practice, 92, (2), pp. 224-237.

Silverman, D. (1993) Interpreting Qualitative Data: Methods for Analysing Talk, Text and Interaction, London: Sage.

Smith, D. (1990) Integrative Therapy, Grand Rapids: Baker Book House.

Smith, J. (1996) 'Beyond the divide between cognition and discourse: using interpretative phenomenological analysis in health psychology', in Psychology \& Health, 11, pp. 261-271.

Smith, J. A., (1997) 'Developing Theory from Case Studies: Self-reconstruction and the Transition to Motherhood', in N. Haynes, (ed.) Doing Quantitative Analysis in Psychology. Hove: Psychology Press.

Smith, J. A. (2010) 'Interpretative phenomenological analysis: A reply to Amedeo Giorgi.' in Journal for the Society of Existential Analysis, 21, (2), pp. 186-192.

Smith, J.; Flowers, P. \& Larkin, M. (2009) Interpretative phenomenological analysis: Theory, Method and Research 2nd ed. London: Sage.

Society for Psychotherapy Research, (2011) SPR Interest Section on Therapist Training and Development. [Online] Available at: https://www.uni-wh.de/en/uwhinternational/research/research-projects/spristad-international-collaborative-study-on-thetraining-and-development-of-psychotherapists/\#faq

Sperry, L. \&. Shafranske. E. (2005) Spiritually Oriented Psychotherapy, Washington DC: APA.

Steele, K. (2014) Sacred Space: Embracing the Spiritual in Person-Centred Therapy, Great Britain: CreateSpace.

Stewart-Sicking, J.A.; Deal, P. \& Fox, J. (2017) 'The Ways Paradigm: A Transtheoretical Model for Integrating Spirituality Into Counseling', in Journal of Counseling \& Development, 95, (2), pp. 233-240.

Strupp, H. (1986) 'Psychotherapy: research and practice and public policy (how to avoid dead ends)' in American Psychologist, 41, pp. 120-130.

Summers, R. \& Barber. J. (2009) Psychodynamic Therapy: A Guide to Evidence-Based Practice, New York: Guilford Press. 
Working with the Waverley integrative framework: Exploring the experience of counsellors, trained in the Waverley integrative framework (WIF), in incorporating the framework into their therapeutic practice.

Sundberg, N. (2001) Clinical Psychology: Evolving Theory, Practice, and Research, Englewood Cliffs: Prentice Hall.

Swinton, J. (2001) Spirituality and Mental Health Care: Rediscovering a 'Forgotten' Dimension, London: Jessica Kingsley.

Swinton, V. (2016) 'Research to develop spiritual pedagogy, awareness and change', in British Journal of Guidance \& Counselling,l 44, (3), pp. 268-276.

Szasz, T. (1974) The Ethics of Psycho-Analysis: The Theory and Method of Autonomous Psychotherapy, London: Routledge \& Keegan Paul.

The Holy Bible, New International Version.

Thompson, C. (2010) Anatomy of the Soul:Surprising Connections Between Neuroscience and Spiritual Practices that can Transform your Life and Relationships, Carollton: Tyndale.

Thorne, B. (1991) Person-Centred Counselling: Therapeutic and Spiritual Dimensions, London: Whurr.

Thorne, B. (1998) Person-centred Counselling and Christian Spirituality: The Secular and the Holy, London: Whurr.

Toren, C. (2002) 'Comparison and Ontogeny'. In: Gingrich, A \& Fox R. (eds.) Anthropology, By Comparison, Abingdon: Routledge, pp. 118-203.

Tryon, W. W. (2014) Cognitive Neuroscience and Psychotherapy: Network Principles for a Unified Theory, San Francisco: Elselvier.

Varela, F. J. \& Thompson, E. T. \& Rosch. E. (1991) The Embodied Mind: Cognitive Science and Human Experience, Cambridge: The MIT Press.

West, W. (2012) Addressing spiritual and religious issues in counselling and psychotherapy. [Online] Available at: https://www.bacp.co.uk/bacp-journals/thresholds/winter-2012/addressing-spiritualand-religious-issues-in-counselling-and-psychotherapy/

[Accessed 1 July 2021].

Wampold, B. E. \&. Imel. Z. E. (2015) The great psychotherapy debate: The evidence for what makes psychotherapy work, 2nd ed. New York: Routledge.

Webb, M.-A. (2019) A Reflective Guide to Gender Identity Counselling, London: Jessica Kingsley Publishers.

West, W. (2000) Psychotherapy \& Spirituality: Crossing the Line between Therapy and Religion, London: Sage.

Westen, D., Novotny, C.A., Thompson-Brenner, H. (2004) 'The Empirical Status of Empirically Supported Psychotherapies: Assumptions, Findings and Reporting in Controlled Clinical Trials', in The Psychological Bulletin, 130, (4), pp. 631-3. 
Working with the Waverley integrative framework: Exploring the experience of counsellors, trained in the Waverley integrative framework (WIF), in incorporating the framework into their therapeutic practice.

Charlotte Wears

Wheeler, S. (1993) 'Reservations about eclectic and integrative approaches to counselling', in Dryden, W. (ed.) Questions and answers on counselling in action, London: Sage, pp. 86-90.

Wilber, K. (2000) Integral Psychology, Boulder: Shambhala Publications.

Wilkinson, H. (2020) 'Book Review' in Journal of Psychological Therapies, 5, (1), pp. 90-99.

Williams, D. \&. Irving. J. (1996) 'Personal growth: Rogerian paradoxes', in British Journal of Guidance and Counselling, 24, (2), pp. 165-172.

Willig, C. (2013) Introducing Qualitative Research in Psychology, 3rd ed. Maidenhead: OUP.

Winnicott, D. (1965) The Maturational Processes and the Facilitating Environment, London: The Hogarth Press and the Institute of Psycho-Analysis.

Winnicott, D. (1971/2005) Playing and Reality, Abinger: Routledge.

Wittgenstein, L. (1953) Philosophical Investigations, Oxford: Blackwell.

Wittgenstein, L. (1972) On Certainty, New York: Harper \& Row.

Wyatt, J. (2002) ' 'Confronting the almighty God'? A study of how psychodynamic counsellors respond to clients' expressions of religious faith, in Counselling and Psychotherapy Research, 2, (3), pp. 177-184.

Yalom, I. D. (1989) Loves Executioner, New York: Basic Books.

Yardley, L. (2000) Dilemmas in qualitative health research., in Psychology and Health, 15, pp. 215228.

Yin, R. (1989) Case Study Research: Design and Methods, 2nd ed. Beverley Hills: Sage.

Zarbo, C., Tasca, G. A, Cattafi, F., Compare, A. (2016) 'Integrative Psychotherapy Works', in Frontiers in Psychology, 6. https://doi.org/10.3389/fpsyg.2015.02021.

\section{About the author}

\section{Charlotte Wears BA (Hons), MA, Counsellor and Psychotherapist, MBACP}

Charlotte is an integrative counsellor and psychotherapist. She has worked for 13 years with young people in schools and has her own private practice, working with adults and young people. Charlotte has just completed her MA at Waverley Abbey College and this article is drawn from her final research project dissertation. With a background in the arts, Charlotte is interested in creative exploration of the self, the world and others, and among other things uses wordcraft, walk-andtalk and the Waverley integrative framework to facilitate this.

Contact: charlotte@whitmoorcounselling

Tel: 07596393483

Website: www.whitmoorcounselling.co.uk 
Working with the Waverley integrative framework: Exploring the experience of counsellors, trained in the Waverley integrative framework (WIF), in incorporating the framework into their therapeutic practice.

\section{Copyright}

Copyright 2021 Charlotte Wears

Charlotte Wears 